\title{
INFLUENCE OF CLIMATE VARIABLES IN THE INITIAL GROWTH OF Corymbia citriodora AND DIFFERENT SPECIES OF EUCALYPTUS
}

\author{
INFLUÊNCIA DAS VARIÁVEIS CLIMÁTICAS NO CRESCIMENTO INICIAL DE \\ Corymbia citriodora E DIFERENTES ESPÉCIES DE EUCALIPTO
}

\section{Nerison Luís POERSCH ${ }^{1}$; Luiz Roberto Terra FRANÇA FILHO² ; Eder Pereira MIGUEL $^{3}$; Gustavo Henrique Miguel da $\mathrm{CRUZ}^{4}$; Karine Letícia FRANCISQUETTE ${ }^{5}$; Sâmela Beutinger CAVALHEIRO ${ }^{6}$}

1. Professor Adjunto da Universidade Federal de Mato Grosso do Sul, Campus de Chapadão do Sul, MS, Chapadão do Sul, MS, Brasil. nerisonp@yahoo.com.br; 2. Acadêmico do Curso de Agronomia da Universidade Federal de Mato Grosso do Sul, Campus de Chapadão do Sul, Chapadão do Sul, MS, Brasil; 3. Professor Adjunto da Universidade de Brasília, Campus Universitário Darcy Ribeiro, Brasília, DF, Brasil; 4. Acadêmico do Curso de Engenharia Florestal da Universidade Federal de Mato Grosso do Sul, Campus de Chapadão do Sul, Chapadão do Sul, MS, Brasil; 5. Acadêmica do Curso de Engenharia Florestal da Universidade Federal de Mato Grosso do Sul, Campus de Chapadão do Sul, Chapadão do Sul, MS, Brasil; 6. Acadêmica do Curso de Mestrado em Agronomia da Universidade Federal de Mato Grosso do Sul, Campus de Chapadão do Sul, Chapadão do Sul, MS, Brasil.

\begin{abstract}
This work aimed to analyze possible differences in growth patterns on Eucalyptus species and to identify the determinants climatic variables on the growth. We evaluated six Eucalyptus species (Eucalyptus camaldulensis, Eucalyptus grandis, Eucalyptus urophylla, Eucalyptus saligna, Corymbia citriodora and Eucalyptus globulus) and a Clone (GG100) implanted in an experimental arrangement of randomized blocks. We collected the collar diameter and height of all plants monthly in the course of a year, in addition to climate data (minimum temperature, maximum and rainfall). Sequentially, we obtained the correlations between the current monthly increments (collar diameter and height) and climatic variables (minimum temperature, maximum and rainfall). The Current Monthly Increment of the Collar diameter (CMI D) was not correlated to the climatic variables evaluated and the Current Monthly Increment of the Height (CMI H) was strongly correlated to the minimum temperature for the species E. camaldulensis, C. citriodora, E. saligna, E. urophylla, E. grandis and the GG100 Clone. The Rainfall showed positive correlations regarding the CMI H only for the Clone (GG100) and E. urophylla. Finally, the species E. camaldulensis, E. urophylla, E. grandis, E. saligna presented a mortality rate under $10 \%$ which is recommended according to the silvicultural criteria.
\end{abstract}

KEYWORDS: Forestry populations. Collar diameter. Plant height. Cerrado.

\section{INTRODUCTION}

Eucalypts originate in Australia, Indonesia, and New Guinea. Eucalyptus spp. were introduced to Brazil in the nineteenth century. The first eucalypts may have been planted in the Botanical Gardens of Rio de Janeiro in 1825 as ornamentals and wind breaks (PEREIRA et al., 2000).

As of 2013, 7.60 million ha were used for agriculture in Brazil. The forestry sector contributed $\$ 56$ billion to the gross national product (GNP) of Brazil. This value represents $1.2 \%$ of the total national income and $24 \%$ of the GNP derived from the agricultural sector. As of 2013, every hectare of trees planted in Brazil added \$7.4 million annually to the GNP. By comparison, soybean, an important crop, added $\$ 4.8 \mathrm{million} / \mathrm{y} / \mathrm{ha}$ and cattle raising contributed $\$ 2.5$ million/y. Eucalyptus plantations constitute approximately $70 \%$ of the total forestry GNP (IBÁ, 2014).
Eucalyptus is the most commonly planted tree in the tropics (EPRON et al., 2013) because of its rapid growth, productivity, adaptability, diversity, and wide range of uses. In Brazil, the total area planted with Eucalyptus is 5.1 million ha. The states of Minas Gerais, São Paulo, Bahia, Mato Grosso do Sul, Rio Grande do Sul, Espirito Santo, and Paraná have 83.6\% of the eucalyptus plantations (ANUÁRIO ESTATÍSTICO DA ABRAF, 2013).

The Cerrado is the second largest biome in Brazil. The largest is the Amazon Forest. The Cerrado is found in the states of Goias, Mato Grosso, Mato Grosso do Sul, Minas Gerais, Tocantins, Bahia, Maranhao, Piaui, Rondonia, Paraná, São Paulo, Distrito Federal, and in parts of Amapa, Roraima, and Amazonas. It is characterized by nutrient-poor soil and seasonal water deficits (MINISTÉRIO DO MEIO AMBIENTE, 2015).

The climate of Chapadão do Sul is mainly seasonal tropical with dry winters. The annual average 
temperature range is $22-23{ }^{\circ} \mathrm{C}$. The maximum temperature is $>40{ }^{\circ} \mathrm{C}$ throughout the year. The minimum temperatures vary frequently and descend to $\leq 0{ }^{\circ} \mathrm{C}$ in May, June, and July. The average rainfall ranges from 1200-1800 $\mathrm{mm}$ during the wet season (October to March). Short drought periods known as "Indian summers" may occur in the middle of the wet season and are problematic for agriculture. Between May to September, monthly rainfall decreases significantly and may decline to zero. The relative humidity falls to $15 \%$ (MARCUZZO et al., 2012).

There is little information concerning eucalyptus adaptation to the Cerrado environment. The eucalyptus species introduced in Brazil have high genetic variability and are amenable to genetic improvement programs (FONSECA et al., 2010). Advances have been made in terms of species characterization, cultivation methods, product quality, propagation, hybridization, and cloning. It is now possible to generate hybrids in both the greenhouse and the field via floral induction on grafted genitors (ROCHA et al., 2007). Although more than seven hundred Eucalyptus species have been identified, only a few with particular traits and target uses are being raised on the plantations. Among these are Corymbia citriodora (formerly, Eucalyptus citriodora), $E$. grandis, E. saligna, E. urophylla, E. camaldulensis, and E. globulus.

Species selection is the first step in reforestation and is determined by the end use of the trees (wood, coal, cellulose) and the edaphoclimatic (soil and climate) conditions of the region. It is necessary to investigate how different genotypes derived from seed or vegetative propagation adapt to various environments (ALCANTRA et al., 2015). Therefore, an objective of this study was to determine empirically the conditions required to optimize new eucalyptus plantations in this region. Although several eucalyptus species have not yet been assessed, some of them could nonetheless be productive in the Brazilian Cerrado. Another goal was to identify seasonal differences in the growth patterns and adaptability of eucalyptus and the climatic conditions that determine tree growth.

\section{MATERIAL AND METHODS}

The experiment began in January 2014 in the experimental area of the University of Mato Grosso do Sul, Chapadão do Sul Campus, located in the town of Chapadão do Sul. The altitude is $820 \mathrm{~m}$. The soil is classified as a red latosol (average texture). According to the Köppen classification system (1936), the climate is tropical humid (Aw) with a wet season from October to April and a dry season between May and September. The average rainfall ranges from 750$1,800 \mathrm{~mm} / \mathrm{y}$, and the annual average temperature ranges from $20-25^{\circ} \mathrm{C}$.

Measurements started in August 2014, seven months after the installation of the experiment. All specimens passed the seedling, development, and hardening stages over a four-month period in a nursery/greenhouse. Six eucalyptus species were used: Eucalyptus camaldulensis, E. grandis, E. urophylla, E. saligna, Corymbia citriodora, E. globulus, and a clone designated GG100, which is a hybrid of $E$. urophylla obtained by vegetative propagation. A randomized block design was used with four replicates. There were 3-m gaps between rows and 2$\mathrm{m}$ intervals between plants. Each plot consisted of four rows of seven trees each, for a total of 28 trees per plot.

We collected both dendrometric and climatic data. The dendrometric data included the collar diameter (sD) and the plant height (Ht). Measurements were made on all trees in each plot on the fifteenth day of every month between August 2014 and July 2015 inclusive. A digital caliper with millimeter precision (ZaaS Precision, Brazil) was used to measure stem diameters. Readings were then converted to centimeters. Plant heights in meters were obtained using a 15-m telescopic ruler. All climate data were collected daily. A max-min thermometer was installed in a white shelter and used for temperature measurements, and rainfall was measured using a pluviometer installed near the experimental site.

All fertilization requirements were determined from chemical analyses of the soil. The following results were obtained: $\mathrm{pH}(\mathrm{CaCl}), 4.9$; organic matter, $31.5 \mathrm{~g} \mathrm{dm}^{-3}$; phosphorus, $13.6 \mathrm{mg} \mathrm{dm}^{-}$ 3; hydrogen + aluminum ratio $(\mathrm{H}+\mathrm{Al})$, 5.4;

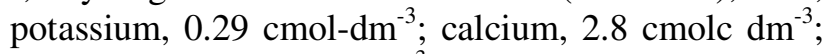

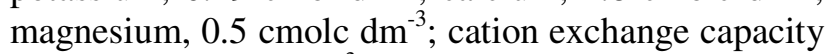

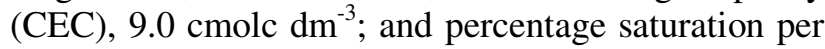
base (V), 39,9. The proportions of clay, sand, and silt were $46 \%, 46 \%$, and $8 \%$, respectively. Crowning, hoeing, ant control and herbicide (glyphosate) application were performed when necessary.

The data was tabulated in Microsoft Excel. ANOVA was performed to identify any significant differences in the average increases in collar diameter 
and plant height during the evaluation period. ANOVA and Tukey's test were run to determine survival rates in the final month (July 2015). Pearson correlation coefficients ( $r$ ) were calculated to verify the influence of temperature and rainfall on the increases in collar diameter and plant height. They can also be evaluated qualitatively on the basis of intensity according to the criteria proposed by CallegariJacques (2003). All statistical analyses were performed with the Genes Computer Software (CRUZ, 2006). Linear correlations were rated as follows:

$--0.00<\mathrm{r}<0.30$ : weak;

$-0.30 \leq \mathrm{r}<0.60$ : moderate;

$--0.60 \leq \mathrm{r}<0.90$ : strong;

$--0.90 \leq \mathrm{r}<1.00$ : very strong.

\section{RESULTS AND DISCUSSION}

\section{Monthly Growth of the Eucalyptus species/clone}

Average collar diameters and plant heights were determined from the data collected over a twelve-month period (Table 1). As of August 2014 (dry season), E. urophylla, E. camaldulensis, E grandis, and E. saligna had the largest average collar diameters. The clone (GG100), E. globulus, and $C$. Citriodora had the smallest average collar diameters.

As of January 2015 (wet season), $E$. urophylla, E. camaldulensis, E. grandis, and E. saligna had the highest collar diameter increase rates. Therefore, there was no significant difference in the data between the two seasons. In the wet season, $C$. citriodora, E. globulus, and GG100 had the largest collar diameters.

In July 2015, one year after the first evaluation, E. urophylla, GG100, E. grandis, E. camaldulensis, and E. saligna had the largest collar diameters. E. globulus and C. citriodora had the smallest average collar diameters. Therefore, there were no significant changes in collar diameter among the species evaluated during the period August 2014 (dry season)--January 2015 (wet season)--July 2015 (dry season). Only GG100 had significantly increased in average collar diameter by the last evaluation (July 2015).

As for the growth averages of plant height (Table 1), it is observed that on August of 2014 (Dry season), the species/clone that obtained the best averages were
POERSCH, N. L. et al.

E. camaldulensis, E. urophylla and E. grandis. In other hand, the Clone (GG100) obtained the lower rate for height of the plants, not differing from the $E$. globulus. On January of 2015 (six months after the first evaluation - Wet season), the higher rates for plant height were for the E. camaldulensis, E. urophylla, E. grandis, Clone (GG100), E. saligna and C. citriodora species, highlighting the Clone (GG100) that presented a quick growth, as expected. The best averages for the plant height were verified for $E$. globulus and $C$. citriodora.

In July 2015, E. grandis, E. saligna, GG100, E. urophylla, and E. camaldulensis had the highest average plant heights, and E. globulus, C. Citriodora, and E. camaldulensis had the lowest (Table 1).

Quiqui et al. (2001) evaluated twelve Eucalyptus species in Paraná (Brazil) over a one-year period. E. grandis had the largest diameter, height, and volume, and Corymbia citriodora had the lowest collar diameter growth rate. Silva et al. (1992) studied five Eucalyptus species in Lassance (Minas Gerais, Brazil) and found that E. camaldulensis had the greatest height increase rate. Azevedo et al., (2015) reported that E. calmaldulensis adapted well to the Cerrado soils in the state of Mato Grosso.

According to the collar diameter and plant height data, after twelve months, the best-adapted species were E. urophylla, E. camaldulensis, E. grandis, E. saligna, and GG100.

\section{Current Monthly Increment (CMI) for collar diameter and plant height}

The current monthly increment (CMI) is a measure of the monthly growth rate of the tree species. It indicates their responses to the climatic and edaphic conditions of their environment. The average CMI was calculated for the collar diameter and the plant height (Figures 1A and 1B).

Figure 1A represents the current monthly increments for collar diameter (CMI D) over twelve months. Maximum increases in collar diameter growth were observed in December 2014 and January 2015. In both April and May 2015, CMI D decreased then increased once again in June and July 2015. Fig. 1B illustrates the current monthly increments for plant height $(\mathrm{CMI} \mathrm{H})$. The plant height growth rate reached a maximum in April 2015 then decreased in June and July 2015. 
Table 1. Averages obtained for the species/clone evaluated during 12 months, regarding collar diameter $(\mathrm{cm})$ and plant height (m), in Chapadão do Sul, Mato Grosso do Sul, Brazil.

\begin{tabular}{|c|c|c|c|c|c|c|c|c|c|c|c|c|}
\hline & \multicolumn{12}{|c|}{ Diameter $(\mathrm{cm})$} \\
\hline Species/Clone & Aug/14 & Sep/14 & Oct/14 & Nov/14 & Dec/14 & Jan/15 & Feb/15 & Mar/15 & Apr/15 & May/15 & Jun/15 & $\mathrm{Jul} / 15$ \\
\hline E. urophylla & $3,35 \mathrm{a}^{*}$ & $3,82 \mathrm{a}$ & $4,48 \mathrm{a}$ & $5,20 \mathrm{a}$ & $6,31 \mathrm{a}$ & $7,48 \mathrm{a}$ & $8,21 \mathrm{a}$ & $8,82 \mathrm{a}$ & $9,07 \mathrm{a}$ & $9,62 \mathrm{a}$ & $10,31 \mathrm{a}$ & $10,98 \mathrm{a}$ \\
\hline E. camaldulensis & $3,35 \mathrm{a}$ & $3,92 \mathrm{a}$ & $4,48 \mathrm{a}$ & $5,07 \mathrm{a}$ & $5,79 \mathrm{ab}$ & $6,82 \mathrm{ab}$ & $7,45 \mathrm{ab}$ & $7,90 \mathrm{abc}$ & $8,34 \mathrm{ab}$ & $8,97 \mathrm{a}$ & 9,59 a & $10,27 \mathrm{a}$ \\
\hline E. grandis & $2,57 \mathrm{ab}$ & $3,45 a b$ & $4,09 \mathrm{a}$ & $4,70 a b$ & $5,70 \mathrm{ab}$ & $6,87 \mathrm{ab}$ & $7,67 \mathrm{ab}$ & $8,19 \mathrm{ab}$ & $8,71 \mathrm{a}$ & $9,31 \mathrm{a}$ & 9,94 a & $10,69 a$ \\
\hline E. saligna & $2,43 a b$ & $2,96 \mathrm{bc}$ & $3,62 \mathrm{ab}$ & $4,27 \mathrm{abc}$ & $5,30 \mathrm{abc}$ & $6,54 \mathrm{abc}$ & 7,13 abc & $7,66 \mathrm{abc}$ & $8,16 \mathrm{abc}$ & $8,73 a b$ & 9,36 & 9,99 a \\
\hline E. globulus & $1,86 \mathrm{bc}$ & $2,36 \mathrm{~cd}$ & 3,01 bc & 3,68 bc & $4,74 \mathrm{bc}$ & $5,62 \mathrm{bc}$ & 6,36 bc & 6,83 bc & 7,02 bc & 7,46 bc & 7,79 & 8,40 \\
\hline C. citriodora & 1,72 bc & $2,14 \mathrm{~cd}$ & 2,75 & 3,39 & $4,21 \quad \mathrm{c}$ & $5,25 \quad c$ & $5,82 \quad c$ & $6,64 \quad c$ & $6,98 \quad c$ & $7,22 \quad \mathrm{c}$ & 7,80 & 8,54 \\
\hline Clone GG100 & $1,41 \quad \mathrm{c}$ & 1,81 & 2,51 & 3,16 & 4,42 & $5,81 \mathrm{bc}$ & $6,60 \mathrm{bc}$ & $7,54 \mathrm{abc}$ & $8,05 \mathrm{abc}$ & $8,90 \mathrm{a}$ & $9,75 \quad \mathrm{a}$ & $10,78 \mathrm{a}$ \\
\hline & \multicolumn{12}{|c|}{ Height $(\mathrm{m})$} \\
\hline E. camaldulensis & $2,15 \mathrm{a}$ & $2,43 \mathrm{a}$ & $2,78 \mathrm{a}$ & $3,08 \mathrm{ab}$ & $3,54 \mathrm{a}$ & $4,02 \mathrm{a}$ & $4,54 \mathrm{ab}$ & $5,00 \mathrm{ab}$ & $5,72 \mathrm{ab}$ & $6,02 \mathrm{abc}$ & $6,33 \mathrm{abc}$ & $6,56 a b c$ \\
\hline E. urophylla & $1,81 \mathrm{ab}$ & $2,07 \mathrm{ab}$ & $2,47 \mathrm{ab}$ & $2,85 \mathrm{abc}$ & $3,49 \mathrm{ab}$ & $4,05 \mathrm{a}$ & $4,65 \mathrm{ab}$ & $5,22 \mathrm{ab}$ & $5,97 \mathrm{ab}$ & $6,33 \mathrm{ab}$ & $6,69 a b$ & $6,96 \mathrm{ab}$ \\
\hline E. grandis & $1,77 \mathrm{ab}$ & $2,18 \mathrm{ab}$ & $2,74 \mathrm{a}$ & $3,21 \mathrm{a}$ & $3,69 \mathrm{a}$ & $4,27 \mathrm{a}$ & $5,03 \mathrm{a}$ & $5,68 \mathrm{a}$ & $6,62 \mathrm{a}$ & $6,99 \mathrm{a}$ & $7,34 \mathrm{a}$ & $7,62 \mathrm{a}$ \\
\hline E. saligna & 1,44 bc & 1,88 bc & $2,36 \mathrm{ab}$ & $2,81 \mathrm{abc}$ & $3,29 \mathrm{ab}$ & $3,88 \mathrm{a}$ & $4,57 \mathrm{ab}$ & $5,17 \mathrm{ab}$ & $6,15 \mathrm{ab}$ & $6,85 \mathrm{a}$ & $7,10 \mathrm{a}$ & $7,29 \mathrm{ab}$ \\
\hline C. citriodora & $1,36 \quad \mathrm{c}$ & $1,64 \mathrm{bcd}$ & $2,07 \mathrm{ab}$ & $2,42 \mathrm{abc}$ & $2,95 \mathrm{ab}$ & $3,63 \mathrm{ab}$ & 4,23 bc & 4,58 bc & 5,16 bc & 5,38 bc & $5,70 \mathrm{bc}$ & 5,99 bc \\
\hline E. globulus & 1,24 & $1,48 \mathrm{~cd}$ & $1,83 \mathrm{~b}$ & $2,13 \quad \mathrm{c}$ & $2,54 \mathrm{~b}$ & $3,05 \mathrm{~b}$ & $3,57 \quad \mathrm{c}$ & $3,92 \quad \mathrm{c}$ & $4,37 \quad \mathrm{c}$ & $4,95 \quad \mathrm{c}$ & $5,22 \quad c$ & $5,45 \mathrm{c}$ \\
\hline Clone GG100 & 0,89 & 1,21 & $1,78 \mathrm{~b}$ & 2,33 & $3,14 \mathrm{ab}$ & $3,91 \mathrm{a}$ & $4,78 \mathrm{ab}$ & $5,40 \mathrm{ab}$ & $6,32 \mathrm{a}$ & $6,74 \mathrm{a}$ & $6,98 \mathrm{ab}$ & $7,24 \mathrm{ab}$ \\
\hline
\end{tabular}

${ }^{*}$ Averages followed by the same letter do not differ by the Tukey test $5 \%$ of error probability. 


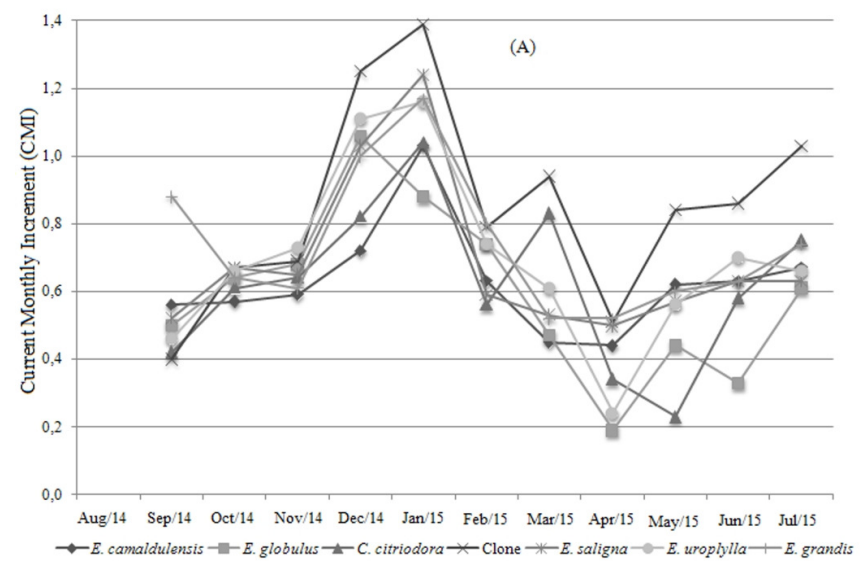

POERSCH, N. L. et al.

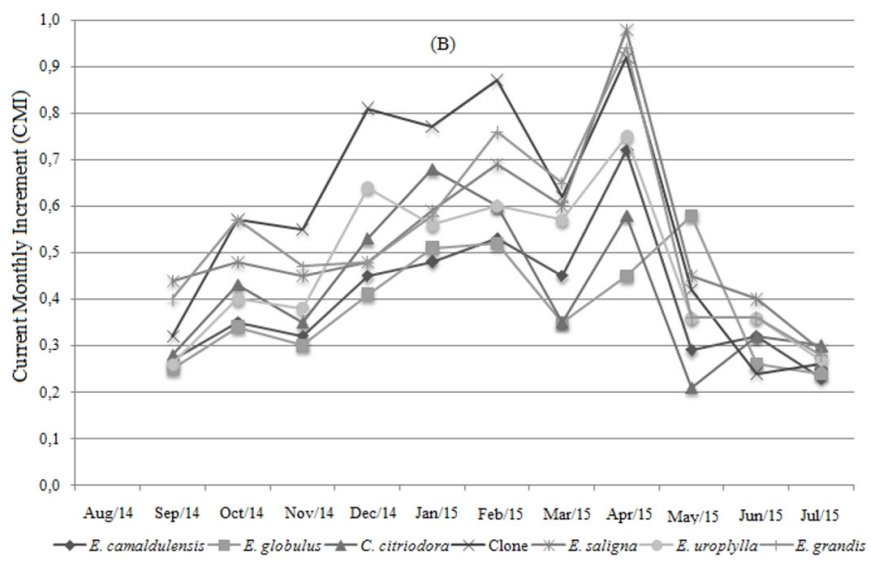

Figure 1. Current Monthly Increments (CMI). A: collar diameter, and B: plant height of the eucalyptus species evaluated over twelve months, in Chapadão do Sul, Mato Grosso do Sul, Brazil.

Machado et al., (2014) studied juvenile Pinus taeda and Araucaria angustifolia and found that for both species, growth rates decreased with temperature and were lowest in the coldest months.

Collar diameter and plant height increase rates vary between seasons and are inversely proportional to each other. According to Charrier et al. (2015), plant height is more affected by climate than collar diameter. The apical meristems are more exposed to the environment than the lateral meristems, and the latter are protected by relatively thick layers of bark.

\section{Survival Rate}

To determine how well the species adapted to the environment, their survival rates were determined at the end of the twelve-month evaluation period.

Table 2 shows that according to Tukey's test, E. camaldulensis, E. urophylla, E. grandis, E. saligna, and GG100 did not differ statistically in terms of survival rate. Nevertheless, E. camaldulensis, E. urophylla, and E. grandis (mortality rates $<5 \%$ ) and E. saligna (mortality rate $<9 \%$ ) were adequately adapted to the environment. Queiroz et al. (2007) reported survival rates of $98.43 \%, 96.9 \%$, and $96.6 \%$ for $E$. grandis, E. camaldulensis, and the hybrid $E$. grandis $\mathrm{x} E$. urophylla, respectively, two months after transplantation. Matos et al. (2012) indicated low mortality rates for juvenile $E$. calmaldulensis and $E$. grandis in northeastern Pará, Brazil.

According to Silva and Angeli (2006), mortality rates $<10 \%$ are preferable for silviculture. Mortality rates $>10 \%$ result in lost productivity and call for reforestation techniques if detected within thirty days. Clone GG100 presented mortality rates > $16 \%$, so it was moderately adapted to the environment. Neither C. citriodora nor E. globulus adapted to the environment.

Table 2. Average eucalyptus survival rates (\%) at the end of twelve months evaluation in Chapadão do Sul, Mato Grosso do Sul, Brazil.

\begin{tabular}{lc}
\hline Species/Clone & Survival Rate (\%) \\
\hline E. camaldulensis & $96,43 \mathrm{a}^{*}$ \\
E. urophylla & $96,43 \mathrm{a}$ \\
E. grandis & $96,43 \mathrm{a}$ \\
E. saligna & $91,96 \mathrm{a}$ \\
Clone GG100 & $83,03 \mathrm{a}$ \\
C. citriodora & $52,68 \mathrm{~b}$ \\
E. globulus & $41,96 \mathrm{~b}$ \\
\hline
\end{tabular}

* Averages followed by the same letter do not significantly differ at the 5\% probability level according to Tukey's test.

\section{Relation between the Current Monthly Increments (CMI) and the climatic variables}

Figure 2 lists the CMI D and the CMI H with temperature (A) and rainfall (B) for the species evaluated. 

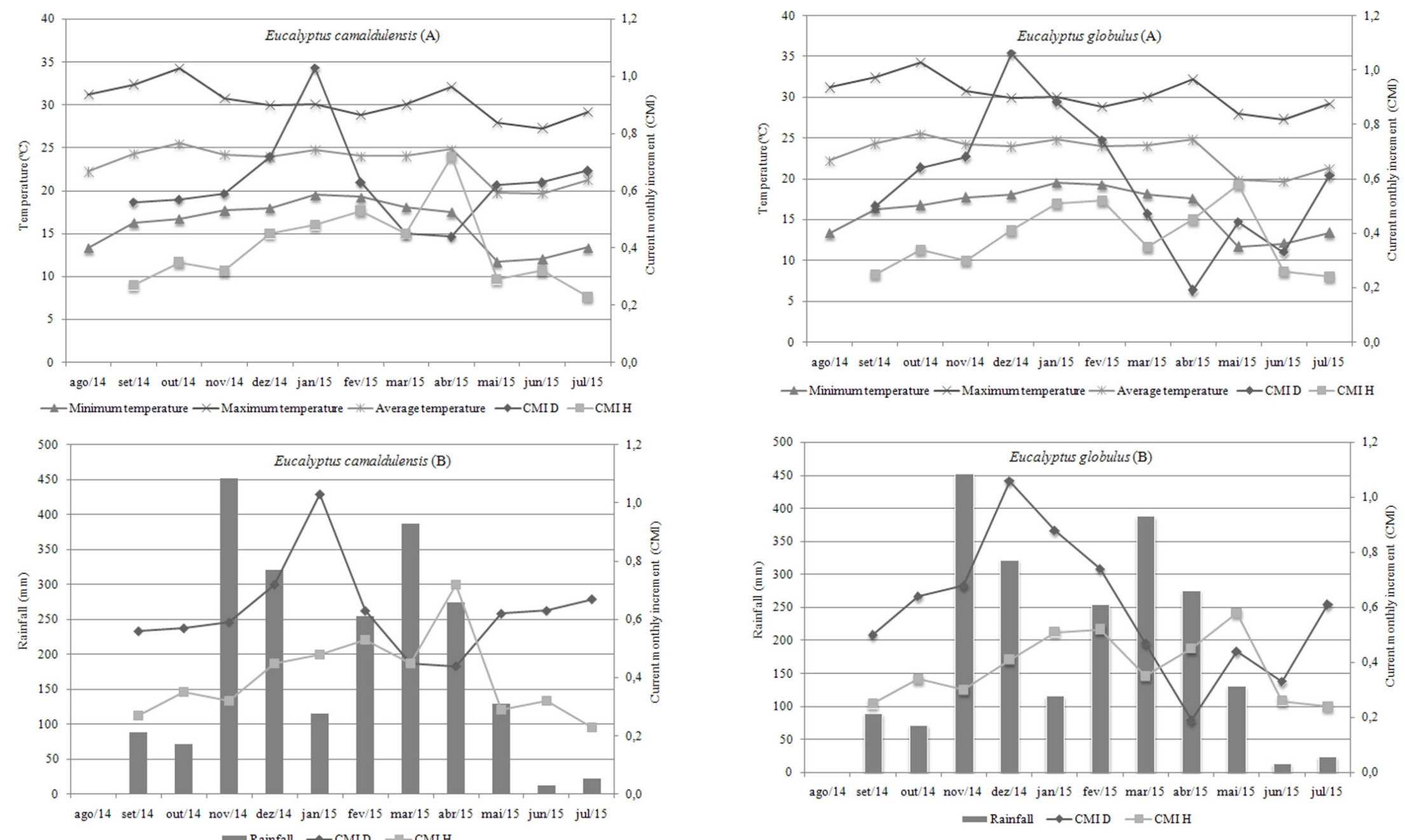

Figure 2. Current monthly increments for collar diameter (CMI D) and height (CMI H) as functions of temperature (A) and rainfall (B) for $E$. camaldulensis and E. globulus in Chapadão do Sul. 

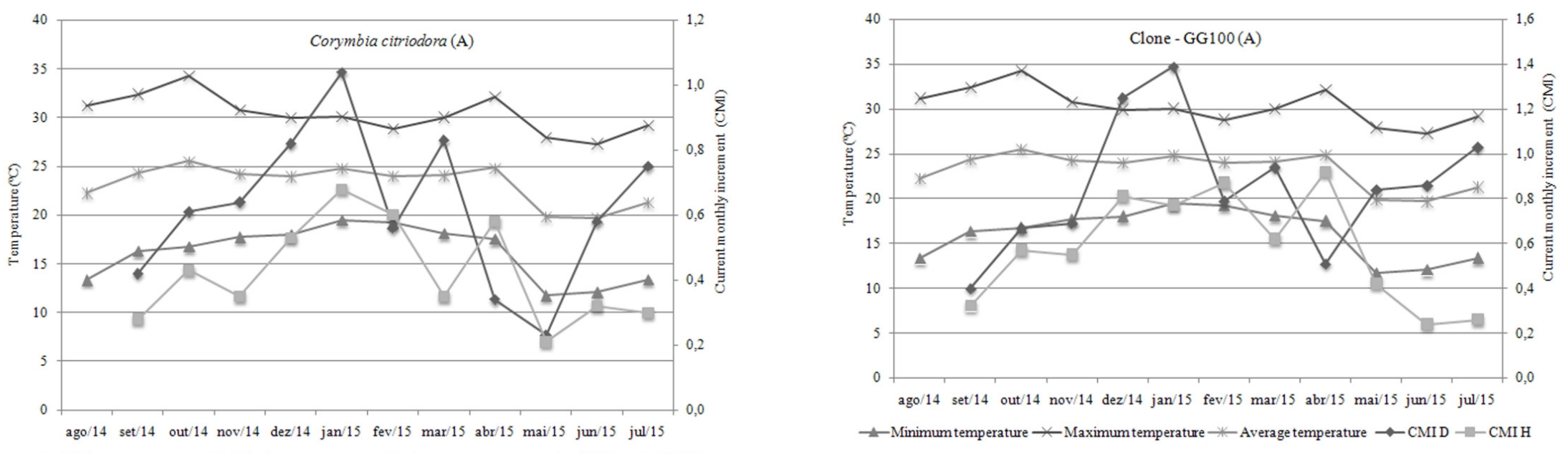

$\rightarrow$-Minimum temperature $\rightarrow$ Maximum temperature $\rightarrow$ Average temperature $\rightarrow$ CMI $\rightarrow-\mathrm{CMI} \mathrm{H}$
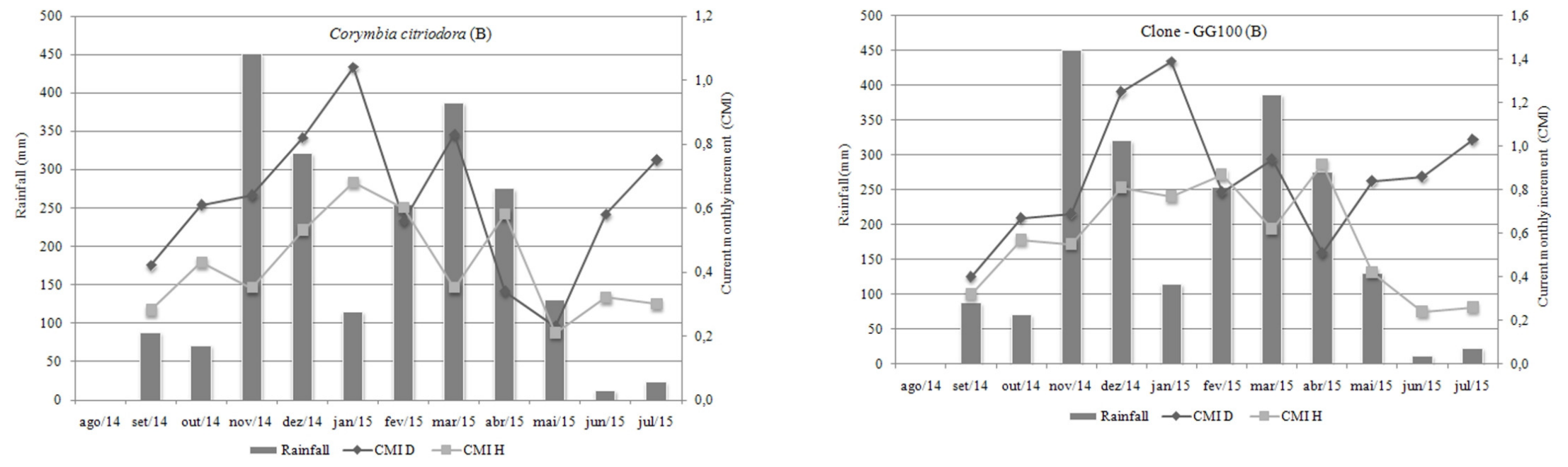

Figure 2. Continuation... Current monthly increments for collar diameter (CMI D) and height (CMI H) as functions of temperature (A) and rainfall (B) for C. citriodora and GG100 in Chapadão do Sul. 

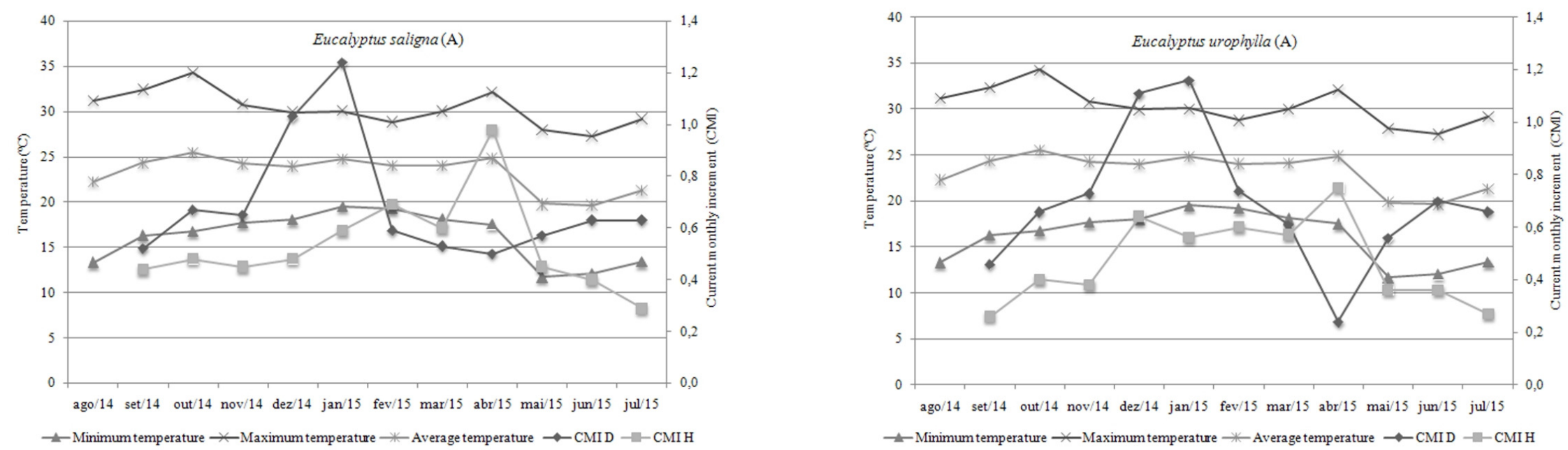

ago/14 set/14 out 14 nov/14 dez/14 jan 15 fev/15 mar 15 abr/15 mai/15 jun 15 jul/15
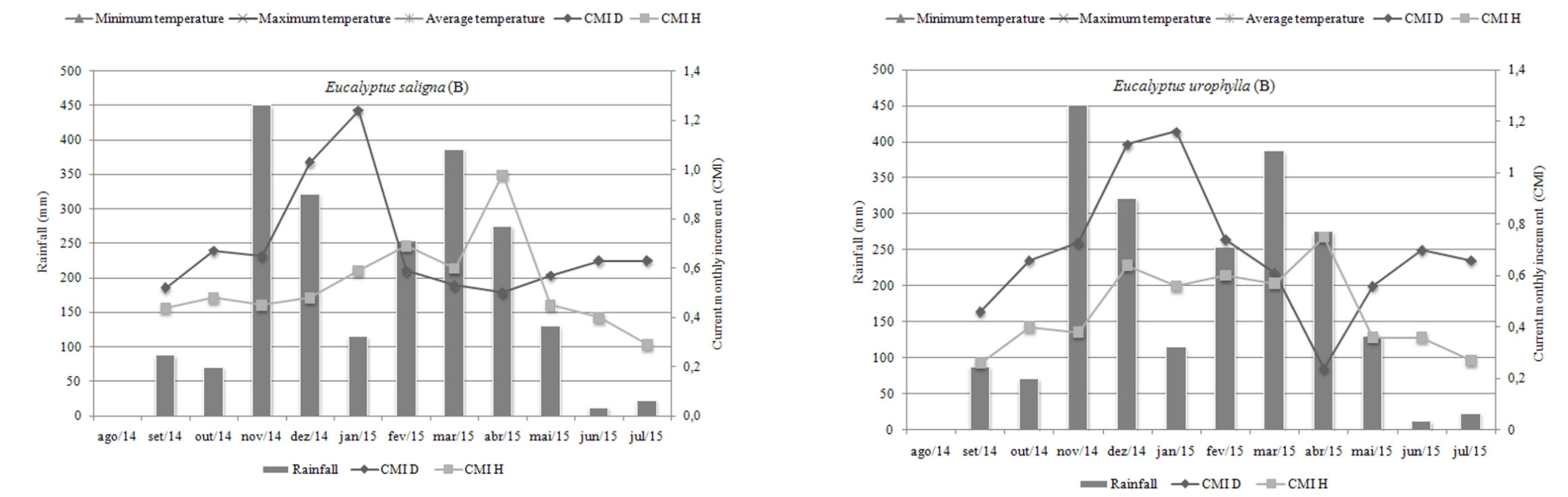

Figure 2. Continuation... Current monthly increments for collar diameter (CMI D) and height (CMI H) as functions of temperature (A) and rainfall (B) for E. saligna and E. urophylla in Chapadão do Sul. 

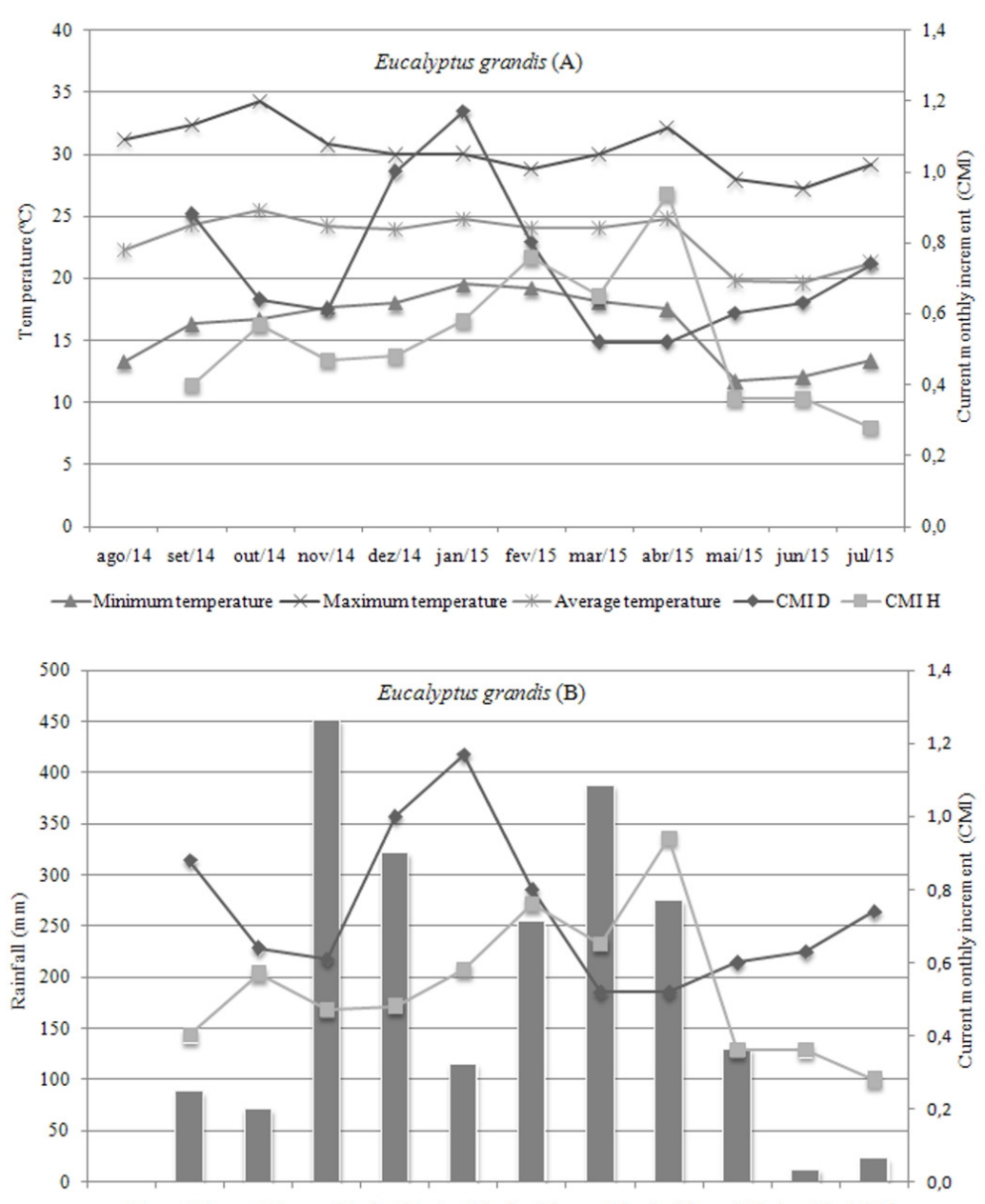

ago/14 set/14 out/14 nov/14 dez/14 jan/15 fev/15 mar/15 abr/15 mai/15 jun/15 ju/15

Figure 2. Continuation... Current monthly increments for collar diameter (CMI D) and height (CMI H) as functions of temperature (A) and rainfall (B) for E. grandis in Chapadão do Sul. 
There were collar diameter growth rate maxima for all species in December 2014 and January 2015, possibly due to high soil moisture levels. Rainfall was elevated in the preceding months (November 2014 and December 2014), and the average minimum temperatures were relatively high in January 2015. Therefore, both rainfall and temperature may be positively correlated with collar diameter.

The collar diameter growth peaks in December and January are associated with high precipitation levels and minimal average temperature increases (DREW et al., 2009). The collar diameter growth rate is highly temperatureregulated (DREW et al., 2008, SETTE JR et al., 2010). In the present study, it was observed that the number of photosynthesis was higher than that of the other species.

In March and April 2015, CMI D decreased significantly, but CMI H reached their maxima (Fig. 2 ). Therefore, collar diameter growth rates increased before those of plant height. Lower collar diameter increments were noted during plant height growth peaks for E. camaldulensis, GG100, E. saligna, E. urophylla, and $E$. grandis. Conversely, plant height growth rates were not necessarily at their lowest when collar diameter increments were at a maximum (Figure 2).

After the onset of the dry season/winter in May 2015, the collar diameter increments increased and the plant height increments decreased. Apparently, the reductions in rainfall and temperature negatively influenced plant growth. In this study, the correlations between the climatic variables and the growth rate changes (CMI D and CMI H) were estimated.

The current monthly increment of the collar diameter (CMI D) was only weakly correlated with the four climatic variables (not significant) (Table 3). None of them significantly affected collar diameter growth rates during the experiment. Sette Junior et al. (2012) obtained similar results when correlating climatic variables and diameter growth rate increments of eucalypts in the state of São Paulo.

Table 3. Pearson correlation matrix of the average current monthly increments (CMI) for the collar diameter and plant height and the climatic variables.

\begin{tabular}{|c|c|c|c|c|c|c|}
\hline Species/Clone & Variables & $\mathrm{CMI} \mathrm{H}^{1}$ & Min. T. & Max. T. & Ave. T. & Rain. \\
\hline \multirow{2}{*}{ E. camaldulensis } & ICM D & 0,45 & 0,35 & $-0,27$ & 0,11 & 0,10 \\
\hline & ICM H & & $0,65^{*}$ & 0,05 & 0,48 & 0,54 \\
\hline \multirow{2}{*}{ E. globulus } & $\mathrm{ICM} \mathrm{D}$ & 0,51 & 0,56 & $-0,08$ & $0,35^{-}$ & 0,35 \\
\hline & ICM H & & 0,38 & $-0,25$ & 0,14 & 0,37 \\
\hline \multirow{2}{*}{ C. citriodora } & $\mathrm{ICM}$ & $0,66^{*}$ & 0,56 & $-0,12$ & $0,33^{-}$ & 0,31 \\
\hline & ICM H & & $0,76^{* *}$ & 0,06 & 0,56 & 0,39 \\
\hline \multirow{2}{*}{ Clone (GG100) } & ICM D & 0,49 & 0,31 & $-0,43$ & 0,01 & 0,22 \\
\hline & ICM H & & $0,80 * *$ & 0,12 & $0,62 *$ & $0,65^{*}$ \\
\hline \multirow{2}{*}{ E. saligna } & ICM D & 0,38 & 0,48 & $-0,14$ & 0,27 & 0,21 \\
\hline & ICM H & & $0,60^{*}$ & 0,11 & 0,47 & 0,53 \\
\hline \multirow{2}{*}{ E. urophylla } & $\mathrm{ICM} \mathrm{D}$ & 0,48 & 0,44 & $-0,29$ & 0,16 & 0,26 \\
\hline & ICM H & & $0,67 *$ & $-0,03$ & 0,45 & $0,62 *$ \\
\hline \multirow{2}{*}{ E. grandis } & $\mathrm{ICM} \mathrm{D}$ & 0,38 & 0,48 & $-0,12$ & 0,28 & 0,13 \\
\hline & ICM H & & $0,70^{*}$ & 0,19 & $0,58 *$ & 0,56 \\
\hline
\end{tabular}

${ }^{1} \mathrm{CMI} \mathrm{D}=$ current monthly increment for collar diameter $(\mathrm{cm})$; $\mathrm{CMI} \mathrm{H}=$ current monthly increment for height; Min. T. = monthly average minimum temperature $\left({ }^{\circ} \mathrm{C}\right)$; Max. T. $=$ monthly average maximum temperature $\left({ }^{\circ} \mathrm{C}\right) ;$ Ave $. \mathrm{T} .=$ monthly average temperature $\left({ }^{\circ} \mathrm{C}\right) ;$ Rain. $=$ rainfall $(\mathrm{mm}) . *^{* *}$ and $*=$ significant at $1 \%$ and $5 \%$ probability, respectively, according to the $t$-test.

The current monthly increments for plant height $(\mathrm{CMI} \mathrm{H})$ had strong positive correlations with the minimum temperature for E. camaldulensis (0.65), C. citriodora (0.76), E. saligna (0.60), E. urophylla (0.67), E. grandis (0.70), and GG100 (0.80) (Table 3). Only E. globulus was not significantly influenced by the minimum temperature. Bamberg (2014) obtained similar results for Acacia mearnsii, Mimosa scabrella, Eucalyptus grandis, and Ateleia glazioveana. For these forestry species, minimum temperature was strongly correlated with annual collar diameter growth, diameter at chest height $(\mathrm{DCH})$, and plant height. Therefore, climatic variables influence plant development.

The CMI H for GG100 and E. grandis was positively and significantly correlated with the average temperature. Rainfall had strong positive correlations with the CMI H only for GG100 (0.65) and E. urophylla (0.62). For E. urograndis, Ferreira 
(2009) obtained the strongest linear correlation estimates between the annual growth rate increases and monthly rainfall, hydric deficit and hydric excess (Table 3 ).

A positive correlation (0.66) was obtained between the CMI D and the CMI $\mathrm{H}$ for $C$. citriodora. Therefore, height increase follows diametric growth in this species (Table 3). The interactions between climate variables and meristematic growth rates in forest species are complex (SETTE JÚNIOR et al., 2016). The correlations between these variables must be examined at the level of the individual tree in order to understand them properly.

This research is important because the information derived from it could be useful for cellulose processors and eucalyptus growers in the state of Mato Grosso do Sul, where much of this crop is produced (ANUÁRIO ESTATÍSTICO DA ABRAF, 2013). Therefore, the present study and others like it may guide forestry producers in their tree species selection.

\section{CONCLUSIONS}

The species/clone presented, initially, a greater growth in collar diameter, then, in plant height.
The reduction of the rain and temperatures influences negatively the plant height.

The Current Monthly Increment for Collar diameter (CMI D) did not correlate significantly to the climatic variables evaluated.

The Current Monthly Increment for Plant Height $(\mathrm{CMI} \mathrm{H})$ is strongly correlated to the minimum temperature for the following species $E$. camaldulensis, $C$. citriodora, E. saligna, $E$. urophylla, E. grandis and Clone (GG100).

Rainfall had a strong positive correlation with the CMI H for GG100 and E. urophylla.

The species best adapted to the geographical region of the study (during its initial phases) were $E$. urophylla, E. camaldulensis, E. grandis, and E. saligna. All of them presented mortality rates < $10 \%$.

\section{ACKNOWLEDGMENTS}

We thank the National Council for Scientific and Technological Development (CNPq) for their support through the Scientific Initiation Scholarship, and the University of Mato Grosso do Sul for the use of their facilities.

RESUMO: Objetivou neste trabalho analisar possíveis diferenças nos padrões de crescimento em espécies de eucalipto e identificar as variáveis climáticas determinantes no crescimento. Foram avaliadas seis espécies de eucalipto (Eucalyptus camaldulensis, Eucalyptus grandis, Eucalyptus urophylla, Eucalyptus saligna, Corymbia citriodora e Eucalyptus globulus) e um Clone (GG100) implantados em arranjo experimental de blocos casualizados. Foram coletados o diâmetro do colo e altura de todas as plantas mensalmente no decorrer de um ano, além dos dados climáticos (temperatura mínima, máxima e precipitação). Sequencialmente foram obtidas correlações entre os incrementos correntes mensais (diâmetro do colo e altura) e as variáveis climáticas (temperatura mínima, máxima e precipitações). O Incremento Corrente Mensal do Diâmetro do Colo não apresentou correlação com as variáveis climáticas avaliadas e o Incremento Corrente Mensal em Altura (ICM H) é fortemente correlacionado com a temperatura mínima para as espécies $E$. camaldulensis, C. citriodora, E. saligna, E. urophylla, E. grandis e o Clone GG100. A precipitação apresentou correlações positiva com o ICM H somente para o Clone (GG100) e para E. urophylla. Por fim, as espécies E. camaldulensis, E. urophylla, E. grandis, E. saligna apresentaram taxa de mortalidade inferior a 10\%, valor este recomendável de acordo com critérios silviculturais.

PALAVRAS-CHAVE: Povoamentos florestais, Diâmetro do colo, Altura de planta, Cerrado.

\section{REFERENCES}

AZEVEDO, L. P. A.; COSTA, R. B.; MARTINEZ, D. T.; TSUKAMOTO FILHO, A. A.; BRONDANI, G. E.; BARRETA, M. C.; AJALA, W. V. Seleção genética em progênies de Eucalyptus camaldulensis em área de cerrado matogrossense. Ciência Florestal, Santa Maria, v. 45, n. 11, p. 2001- 2006. 2015. https://doi.org/10.1590/0103-8478cr20131557 
ALCÂNTRA, B. K.; PIZZAIA, D.; PIOTTO, F. A.; BORGO, L.; BRONDANI, G. E.; AZEVEDO, R. A. Temporal dynamics of the response to Al stress in Eucalyptus grandis $\times$ Eucalyptus camaldulensis. Anais da Academia Brasileira de Ciências, Rio de Janeiro, v. 87, n. 2, p. 1063-1070. 2015.

ANUÁRIO ESTATÍSTICO ABRAF 2013: ano base 2012. Brasília, DF, 2013. Disponível em: <http://www.abraflor.org.br/estatisticas/ABRAF13/ABRAF13_BR.pdf>. Acesso em: 16 set. 2015.

BAMBERG, R. Análise da influência das variáveis meteorológicas no crescimento em diâmetro e altura de quatro espécies florestais. 2014. 56 f. Dissertação (Mestrado em Engenharia Florestal) - Programa de PósGraduação em Engenharia Florestal, Universidade Federal do Paraná, Curitiba, 2014.

CALLEGARI-JACQUES, S. M. Bioestatística: princípios e aplicações. Porto Alegre: Artmed, 2003. 264 p.

CHARRIER, G.; NGAO, J.; SAUDREAU, M.; AMÉGLIO, T. Effects of environmental factors and management practices on microclimate, winter physiology, and frost resistance in trees. Frontiers in Plant Science, Lausanne, v. 6, n. 259, p. 1-19. 2015. https://doi.org/10.3389/fpls.2015.00259

CRUZ, C. D. Programa GENES: Biometria. Viçosa: UFV, 2006. 382 p.

DREW, D. M.; GRADY, A. P.; DOWNES, G. M.; READ, J.; WORLEDGE, D. Daily patterns of stem size variation in irrigated and nonirrigated Eucalyptus globulus. Tree Physiology, Oxford, v.28, n. 10, p.1573-1581, 2008. https://doi.org/10.1093/treephys/28.10.1573

DREW, D. M.; GEOFFRE, Y. M.; DOWNES, G. M.; GRADY, A. P.; READ, J.; WORLEDGE, D. High resolution temporal variation in wood properties in irrigated and non-irrigated Eucalyptus globules. Annals of Forest Science, Paris, v.66, n. 4, p.1-10, 2009.

EPRON, D.; NOUVELLON, Y.; MARESCHAL, L.; MOREIRA, R. M. E.; KOUTIKA, L. S.; GENESTE, B.; DELGADO-ROJAS, J. S.; LACLAU, J. P.; SOLA, G.; GONÇALVES, J. L. D. M.; BOUILLET, J. P.

Partitioning of net primary production in Eucalyptus and Acacia stands and in mixed-species plantations: Two case-studies in contrasting tropical environments. Forest Ecology and Management, Murroe, v. 301, p.102111. 2013. https://doi.org/10.1016/j.foreco.2012.10.034

FERREIRA, M. Z. Modelagem da influência de variáveis no crescimento e na produção de Eucalyptus sp. 2009. 101 f. Tese (Doutorado em Engenharia Florestal) - Programa de Pós-Graduação em Engenharia Florestal, Universidade Federal de Lavras, Lavras, 2009.

FONSECA, S. M., RESENDE, M. D. V., ALFENAS, A. C., GUIMARÃES, L. M. S., ASSIS, T. F. GRATTAPAGLIA, D. Manual Prático de Melhoramento Genético do Eucalipto. Viçosa: UFV, 2010, $200 \mathrm{p}$.

IBÁ. Indústria brasileira de árvores, 2014. Disponível em:

http://www.iba.org/images/shared/iba_2014_pt.pdf. Acesso em: 01 set. 2015.

KÖPPEN, W. Das geographische system der klimate. In: W. KÖPPEN; R. GEIGER. (Ed.). Verlag von Gebrüder Borntraeger. Berlin: Gebrüder Borntraeger, 1936. p. 1-44.

MACHADO, S. A.; ZAMIN, N. T.; NASCIMNETO, R. G. M.; SANTOS, A. A. P. Efeito de Variáveis Climáticas no Crescimento Mensal de Pinus taeda e Araucaria angustifolia em Fase Juvenil. Floresta e Ambiente, Rio de Janeiro, v. 21, n. 2, p. 170-181. 2014.

MARCUZZO, F. F. N.; CARDOSO, M. R. D.; FARIA, T. G. Chuvas no cerrado da região centro-oeste do Brasil: análise histórica e tendência futura. Ateliê Geográfico, Goiânia, v. 6, n. 2, p.112-130. 2012. 
MATOS, G. S. B.; SILVA, G. R.; GAMA, M. A. P.; VALE, R. S.; ROCHA, J. E. C. Desenvolvimento inicial e estado nutricional de clones de eucalipto no nordeste do Pará. Acta Amazonica, Manaus, v. 42. n. 4, p. 491500. 2012. https://doi.org/10.1590/S0044-59672012000400006

MINISTÉRIO DO MEIO AMBIENTE. Bioma Cerrado. Disponível em:

$<$ http://www.mma.gov.br/biomas/cerrado>. Acesso em: 10 de setembro de 2015.

PEREIRA, J. C. D.; STURION, J. A.; HIGA, A. R.; HIGA, R. C. V.; SHIMIZU, J. Y. Características da madeira de algumas espécies de eucalipto plantadas no Brasil. Colombo: Embrapa Florestas, 2000. 113 p.

QUEIROZ, M. M.; LELES, P. M. S.; OLIVEIRA NETO, S. N.; FERREIRA, M. A. Comportamento de materiais genéticos de eucalipto em Paty do Alferes, RJ. Floresta e Ambiente, Rio de janeiro, v. 16, n. 1, p. 1$10,2009$.

QUIQUI, E. M. D.; MARTINS, S. S.; SHIMUZU, J. Y. Avaliação de espécies e procedências de Eucalyptus para o Noroeste do Estado do Paraná. Acta Scientiarum Agronomy, Maringá, v. 23, n. 5, p. 1173-1177, 2001.

ROCHA, M. G. B.; PIRES, I. E.; ROCHA, R. B.; XAVIER, A.; CRUZ, C. D. Seleção de genitores de Eucalyptus grandis e de Eucalyptus urophylla para produção de híbridos interespecíficos utilizando REML/BLUP e informação de divergência genética. Revista Árvore, Viçosa, v. 31, n. 6, p.977-987. 2007. https://doi.org/10.1590/S0100-67622007000600001

SETTE JÚNIOR, C. R; TOMAZELLO FILHO, M.; DIAS, C. T. S., LACLAU, J. P. Crescimento em diâmetro do tronco das árvores de Eucalyptus grandis e relação com as variáveis climáticas e fertilização mineral. Revista Árvore, Viçosa, v. 22, n. 4, p. 771-783, 2010.

SETTE JUNIOR, C. R., TOMAZELLO FILHO, M., LOUSADA, J. L.; LACLAU, J. P. Sazonalidade do incremento em diâmetro do tronco de árvores de Eucalyptus grandis pelo uso de dendrômetros. Ciência Florestal, Santa Maria, v. 22, n. 4, p. 771-783. 2012.

SETTE JUNIOR, C. R., TOMAZELLO FILHO, M., LOUSADA, J. L.; LOPES, D.; LACLAU, J. P. Relationship between climate variables, trunk growth rate and wood density of Eucalyptus grandis w. mill ex maiden trees. Revista Árvore, Viçosa, v. 40, n. 2, p. 337-346. 2016.

SILVA, H. D.; PIRES, I. E.; ARAÚJO, F. D. Comportamento silvicultural e aptidão para produção de carvão de cinco espécies de Eucalyptus, na região dos cerrados de Minas Gerais. Boletim de Pesquisa Florestal, Colombo, n. 24/25, p. 71-78, 1992.

SILVA, P. H. M.; ANGELI, A. Implantação e manejo de florestas comerciais. Documentos florestais, $\mathrm{n}^{\circ} 18$. São Paulo: IPEF, 2006, 13 p. 